\title{
Penerapan Model Pembelajaran Make A Match untuk Meningkatkan Hasil Belajar IPA Materi Organ Peredaran Darah dan Fungsinya
}

\author{
*Sulhan ${ }^{1}$
}

${ }^{1}$ SDN Candiwatu Pacet, Mojokerto, Indonesia

\author{
A R T I C L E I N F O \\ Article history: \\ 25 December 2019 \\ Received in revised \\ form \\ 01 January 2020 \\ Accepted 25 January \\ 2020 \\ Available online 28 \\ February 2020

Kata Kunci:
Metode Make a Match,
meningkatkan Hasil
Belajar, IPA \\ Keywords: \\ Make a Match method, \\ improve learning \\ outcomes, natural \\ science.
}

A B S T R A K

Pelajaran IPA merupakan pelajaran yang kurang diminati siswa karena dianggap sebagai pelajaran yang sulit. Hal ini menyebabkan timbul berbagai masalah baik bagi guru maupun siswa. Salah satu penyebabnya adalah guru belum menggunakan alat peraga yang sesuai. Penelitian ini bertujuan untuk meningkatkan pemahaman tentang organ peredaran darah dan fungsinya dalam kegiatan belajar mengajar pada mata pelajaran IPA di kelas V SD Negeri Candiwatu, Kecamatan Pacet, Kabupaten Mojokerto. Setelah dilakukan observasi dan evaluasi dalam pembelajaran pada mata pelajaran IPA kelas $\mathrm{V}$ materi Organ peredaran darah dan fungsinya maka dapat diketahui bahwa ketidakberhasilan ditetapkan sebesar 75,00 serta adanya ketidakaktifan dan ketidakpahaman siswa pada konsep organ peredaran darah dan fungsinya sehingga diperlukan adanya perbaikan pembelajaran. Dari analisis data nilai hasil evaluasi siklus II jika dibanding dengan siklus I terdapat kenaikan yang sangat berarti. Pada siklus I dari 23 siswa diperoleh nilai rata-rata kelas 65.5, nilai 70 keatas dengan 17 siswa atau $60 \%$, siswa mendapat nilai dibawah 60 dan 6 siswa atau 40\%, sedangkan pada siklus II dari 23 siswa diperoleh nilai rata-rata kelas 8,8 dengan 21 siswa nilai 70 keatas atau 95\% siswa mendapat nilai 60 hanya 2 siswa atau 5\%, Maka pelaksanaan siklus II telah berhasil meningkatkan prestasi belajar organ peredaran darah dan fungsinya di SDN Candiwatu Kec. Pacet Kab. Mojokerto dengan standar keberhasilan 75,00. Hal ini menunjukkan bahwa metode Make a Macth yang digunakan peneliti terbukti dapat meningkatkan aktifitas dan hasil belajar siswa kelas V SDN Candiwatu Pacet Kab. Mojokerto Tahun Pelajaran $2018 / 2019$.

\section{A B S T R A C T}

Natural science was the subject that less attractive to students because it was considered as difficult subject. This caused various problems both for teachers and students. One reason was the teacher had not use the appropriate teaching aids. This research aimed to improve understanding of blood circulation organs and their functions in teaching and learning activities in natural science subject on grade $V$ of Candiwatu elementary school, Pacet district, and Mojokerto regency. After observing and evaluating the natural science subject on grade $V$ of blood circulation organs and its function, it could be seen that the failure was 75.00 as well as the inactivity and lack understanding of students on the concept blood circulation organs and their functions, so that learning improvements were needed. From the data analysis on the second cycle when compared with the first cycle there was a very significant improvement. On the first cycle, there was 23 students obtained the average score 65.5, there was 17 students got score above 70 and 6 students got the score under 60 . While on the second cycle there was 23 students obtained the average score 8.8. There was 21 students got the score above 70 and only 2 students got the score of 60. Then, the implementation on the second cycle has succeeded in improving the learning improvement of blood circulation organs and their functions in SDN Candiwatu, Pacet district, Mojokerto regency with the standard of success 75.00. This showed that the Make a Match method used by researcher proved to be able to improve the activities and learning outcomes on fifth grade students of SDN Candiwatu Pacet district, Mojokerto regency in academic year 2018/2019. 


\section{Pendahuluan}

Pendidikan merupakan upaya untuk meningkatkan sumber daya manusia. Agar tercipta manusia yang cerdas dan maju diperlukan peningkatan mutu pendidikan.Mutu pendidikan sangat erat kaitannya dengan mutu guru, karena guru sebagai ujung tombak kegiatan pendidikan. Proses pembelajaran akan optimal apabila guru mampu merencanakan pelaksanaan sampai dengan evaluasi. Menurut (Suryosubroto, 1997) proses belajar mengajar meliputi kegiatan yang dilakukan guru mulai dari perencanaan, pelaksanaan sampai evaluasi, dan program tidak lanjut. Pernyataan tersebut mengandung makna bahwa pembelajaran tidak lepas dari evaluasi.

Pelajaran IPA merupakan pelajaran yang kurang diminati siswa, karena dianggap sebagai pelajaran paling sulit. Hal ini menyebabkan timbul berbagai masalah baik bagi guru maupun orang tua siswa. Salah satu penyebabnya adalah guru belum menggunakan alat peraga yang sesuai. Guru belum menyadari beberapa hal dalam mengajar IPA seperti : 1) Guru kurang memahami bahwa kecepatan berpikir siswa berbeda-beda. 2) Guru sering menyampaikan konsep kurang memikirkan pola pikir siswa. Dan 3) Guru kurang memahami bahwa pola berpikir siswa SD bersifat konkrit menuju bersifat abstrak.

Agar tercapai tujuan yang diinginkan guru harus memikirkan cara penyampaian materi secara efektif agar mudah diterima siswa secara nyata yaitu dengan menggunakan alat peraga yang sesuai, metode yang bervariasi serta evaluasi yang tepat. Penguasaan materi pelajaran IPA dengan kompetensi dasarorgan eredaran darah dan fungsinya di kelas V SD Negeri Candiwatu Pacet, Kabupaten Mojokerto pada tahun pelajaran 2018/2019 dengan daya serap $65 \%$ karena hanya 15 dari 23 siswa yang telah memenuhi Kriteria Ketuntasan Minimal (KKM) yaitu 7,0 Hal ini menunjukkan sebagian besar siswa SD Negeri Candiwatu mengalami kesulitan dalam mata pelajaran IPA khususnya pada materi organ peredaran darah dan fungsinya. Masalah tersebut dapat mengganggu dan menghambat siswa untuk mencapai prestasi belajar yang tinggi.

Hasil belajar merupakan bagian terpenting dalam pembelajaran (Sudjana, 2010) mendifinisikan hasil belajar siswa pada hakekatnya adalah perubahan tingkah laku sebagai hasil belajar dalam pengertian yang lebih luas mencangkup bidang kognitif, efektif dan psikomotorik. (Dimyati \& Mudjiono, 2016) juga menyebutkan hasil belajar merupakan hasil dari suatu interaksi tindakan belajar dan tindakan mengajar. Dari sisi guru tindakan mengajar diakhiri dengan proses evaluasi hasil belajar, dari sisi siswa hasil belajar merupakan berakhirnya pelajaran dari puncak proses belajar.

Secara umum pengertian hasil belajar adalah perubahan perilaku dan kemampuan secara keseluruan yang dimiliki oleh siswa setelah belajar, yang wujudnya berupa kemampuan kognitif, afektif dan psikomotor ( bukan hanya salah satu aspek potensi saja) yang disebabkan pengalaman.

Definisi hasil belajar lainnya bisa juga diartikan sebagai sesuatu yang dicapai atau diperoleh siswa berkat adanya usaha atau fikiran yang mana hal tersebut dinyatakan dalam bentuk penguasaan, pengetahuan dan kecakapan dasar yang terdapat dalam berbagai aspek kehidupan sehingga nampak pada diri individu penggunaan penilaian terhadap sikap, penggetahuan, kecakapan dasar dan perubahan tingkah laku secara kuantivitas. Setelah suatu proses belajar berakhir, maka siswa memperoleh suatu hasil belajar.

Hasil belajar mempunyai peranan penting dalam proses pembelajaran. Tujuan utama yang ingin dicapai dalam kegiatan pembelajaran adalah hasil belajar. Hasil belajar di gunakan untuk mengetahui sebatas mana siswa dapat memahami serta mengerti materi tersebut. Jadi hasil belajar adalah prestsi belajar yang dicapai siswa dalam proses kegiatan belajar mengajar dengan membawa suatu perubahan dan pembentukan tingkah laku seseorang. Hasil belajar sebagi pengukuran dari penilaian kegiatan belajar atau proses belajar dinyatakan dalam symbol, huruf maupun kalimat yang smenceritakan hasil yang sudah dicoba oleh setiap anak pada periode tertentu.

Hasil belajar juga dapat dilihat melalui kegiatan evaluasi yang bertujuan untuk mendapatkan data pembuktian yang akan menunjukkan tingkat kemampuan siswa dalam mencapai tujuan pembelajaran. Hasil belajar siswa ini dipengaruhi oleh kemampuan siswa dan kualitas pengajaran. Kualitas pengajaran yang dimaksud adalah profesionalitas dan keahlian yang dimiliki oleh guru. Artinya kemampuan dasar guru baik dibidang kognitif ( intelektual), bidang sikap (afektif),dan bidang perilaku (psikomotorik) sangat berpengaruh dalam menentukkan hasil belajar siswa. Hasil Belajar siswa juga di pengaruhi oleh beberapa faktor diantaranya faktor internal yaitu faktor yang ada dalam diri individu yang sedang belajar. Faktor internal ini meliputi faktor jasmaniah dan faktor psikologis. Lalu ada faktor Eksternal yaitu faktor yang ada diluar individu. Faktor eksternal meliputi faktor keluarga, sekolah dan masyarakat.

Pengertian hasil belajar menurut (Suprijono, 2013) adalah perubahan perilaku secara keseluruhan bukan hanya salah satu aspek potensi kemanusiaan saja. Menurut (Jihad Asep, 2012) Pengertian hasil belajar merupakan pencapaian bentuk perubahan perilaku yang cenderung menetap dari ranah kognitif, 
efektif dan psikomotik dari proses belajar yang dilakukan dalam waktu tertentu, sedangkan (Hamalik, 2004) menurut mendifinisikan hasil belajar sebagai tingkat penguasaan yang di capai oleh pelajar dalam mengikuti proses belajar mengajar sesuai dengan tujuan pendidikan yang ditetapkan, dan Menurut (Susanto, 2013)hasil belajar diartikan tingkat keberhasilan siswa dalam mempelajari materi pelajaran disekolah yang dinyatakan dalam skor yang diperoleh dari hasil test mengenal sejumlah materi pelajaran tertentu

Meurut Adi dalam (Lestari, N, 2017) peningkatan adalah proses, cara, perbuatan untuk menaikkan sesuatu atau usaha kegiatan untuk memajukan sesuatu ke suatu arah yang lebih baik lagi dari pada sebelumya. Sedangkan dalam kamus bahasan Indonesia peningkatan berasal dari kata tingkat yang berarti berlapislapis dari sesuatu yang tersususun sedemikian rupa, sehingga membentuk suatu susunan yang ideal, sedangkan peningkatan adalah kemajuan dari seseorang dari tidak tahu menjadi tahu, dari tidak bisa menjadi bisa.

Untuk meningkatkan motivasi dan penguasaan siswa pada materi, penulis melakukan perbaikan pembelajaran yaitu dengan menerapkan metode Make a Match. Disamping untuk memperbaiki pembelajaran, pelaksanaan perbaikan pembelajaran ini. Laporan ini dibuat berdasarkan catatan yang dibuat ketika merancangkegiatan perbaikan, selama pelaksanaan, observasi dan diskusi dengan temansejawat dan supervisor. Pelaksanaan perbaikan pembelajaran dilakukan dalam dua siklus pada mata pelajaran IPA kelas V ini.

Model pembelajaran Make a Match merupakan salah satu jenis dari model pembelajaran kooperatif, yakni bentuk pembelajaran dengan cara siswa belajar dan bekerja dalam kelompok-kelompok kecil secara kolaboratif yang anggotanya terdiri dari empat sampai enam orang dengan struktur kelompok yang bersifat heterogen. Model Make a Match atau mencari pasangan merupakan salah satu alternatif yang dapat diterapkan kepada siswa. Penerapan metode ini dimulai dari teknik yaitu siswa disuruh mencari pasangan kartu yang merupakan jawaban/soal sebelum batas waktunya, siswa yang dapat mencocokkan kartunya diberi poin. Teknik pembelajaran Make a Match atau mencari pasangan dikembangkan oleh Lorna Curran dalam (Kurnia, 2014)

Salah satu keunggulan tehnik ini adalah siswa mencari pasangan sambil belajar mengenai suatu konsep atau topik dalam suasana yang menyenangkan. Berdasarkan dari pendapat di atas dapatdisimpulkan bahwa model pembelajaran Make a Match adalah salah satu model pembelajaran kooperatif yang menuntut siswa untuk mencari pasangan kartusoal dan jawaban yang telah dibuat oleh guru dengan batas waktu yang telah ditentukan agar tercipta kerjasama antara siswa yang satu dengan siswa yang lain. Selain itu, model pembelajaran Make a Match membutuhkan ketelitian, kecermatan, ketepatan, dan kecepatan siswa dalam memasangkan/mencocokkan kartu yang dipegang sambil belajar mengenai suatu konsep dalam suasana yang menyenangkan. Metode ini dapat digunakan untuk membangkitkan aktivitas peserta didik belajar dan cocok digunakan dalam bentuk permainan. Model pembelajaran dengan mencari pasangan melalui kartu pertanyaan dan jawaban yang harus ditemukan dan didiskusikan oleh peserta didik. Model ini dikembangkan oleh Lorna Curran dalam (Kurnia, 2014) dalam bukunya Language Arts and Cooperative Learning Lessons for The Little One. Inti dari model tersebut bagaimana peserta didik dapat mencocokkan kartunya dalam waktu yang telah ditentukan.

Pendidikan adalah upaya memanusiakan manusia muda. Pengangkatan manusia muda ke taraf insaniharus diwujudkan di dalam seluruh proses atau upaya pendidikan. Pengertian tersebut mirip dengan pendapat Thompson dalam (Daliyawati, 2016) yang menyatakan bahwa pendidikan adalah pengaruh lingkungan atas individu untuk menghasilkan perubahan-perubahan yang tetap di dalam kebiasaan-kebiasaan, pemikiran, sikap-sikap, dan tingkah laku. (Tilaar, 1999) merumuskan hakikat pendidikan sebagai suatu proses menumbuhkembangkan eksistensi peserta didik yang memasyarakat, membudaya, dalam tatakehidupan yang berdimensi lokal, nasional, dan global.

Atas dasar pemahaman tentang beberapadefinisi pendidikan maka dapat didefinisikan Pendidikan Sekolah Dasar bukan hanya memberi bekal kemampuan intelektual dasar dalam membaca, menulis dan berhitung saja melainkan juga sebagai proses mengembangkan kemampuan dasar peserta didik secara optimal dalam aspek intelektual, sosial, dan personal, untuk dapat melanjutkan pendidikan di SLTP atau yang sederajat. Pembelajaran yang berkualitas merupakan suatu interaksi semua komponen yang terlibat secara efektif dan efisien dalam pencapaian tujuan. Pembelajaran akan berkualitas jika tujuan, metode, media, materi,siswa, sumber belajar, dan pembelajaran dapat berinteraksi bermakna dan dapat menambah nilai lebih kepada siswa dan guru. Organ peredaran darah dan fungsinya merupakan pokok bahasan yang harus dipelajari oleh siswa kelas V SDN Candiwatu, Pacet Kab. Mojokerto diharapkan bermanfaat bagi diri siswa sendiri dan orang lain. Berdasarkan pengamatan dan pengalaman bahwa pembelajaran organ darah dan fungsinya kurang diminati oleh siswakelas V SDN Candiwatu Pacet Mojokerto, hal ini dikarenakan pembelajarannya yang hanya berisi teori-teori tanpa membuktikan kebenarannya. Belum ada usaha inovasi dalam pembelajarannya, aktivitas siswa dalam memperoleh 
pengetahuan tentang organ darah dan fungsinya dan hanya melalui metode ceramah dan tanya jawab. Hasil yang diperoleh adalah bertambahnya pengetahuan tentang rangkaian seri dan paralel dari pembelajar berdasarkan pengetahuan guru dan buku sumber. Pada akhirnya siswa belum bisa mempraktekkan berdasarkan pengetahuan dan pengalamannya tantang organ darah dan fungsinya. Tujuan pembelajaran tentang Organ peredaran darah dan fungsinya akan tercapai jika menggunakan metode pembelajaran yang tepat pada siswa kelas V SD Negeri Candiwatu, dan ditingkatkan sesuai dengan kondisi yang ada. Terutama aktivitas belajar siswa dalam memperoleh pengetahuan dan pengalaman tentang organ darah dan fungsinya. Oleh karena itu diperlukan suatu usaha untuk mencari, menetapkan dan mengembangkan metode pembelajaran yang tepat dan sesuai dengan kondisi siswa. Untuk itu peneliti mengambil sebuah penelitian dengan judul Penerapan Model Pembelajaran Make A Match Untuk Meningkatkan Hasil Belajar Ipa Materi "Organ Peredaran Darah Dan Fungsinya" Siswa Kelas V Sdn Candiwatu Pacet Kab. Mojokerto.

\section{Metode}

Kegiatan yang dilakukan oleh peneliti pada tahap perencanaan adalah: 1)Peneliti melakukan analisis kurikulum untuk menentukan standar kompetensi dan kompetensi dasar yang disampaikan kepada siswa dengan menggunakan model pembelajaran Make a Match Membuat RPP siklus I dengan model pembelajaran Make a Match, 2) Membuat lembar observasi siklus I untuk melihat bagaimana kondisi belajar mengajar dikelas ketika latihan dan kerja kelompok dilaksanakan. 3) Membuat Lembar Kerja Siswa siklus I 4) Membentuk kelompok yang bersifat heterogen baik dari segi kemampuan akademis, jenis pembelajaran dengan menggunakan media pembelajaran Make a Match pada siklus I dan 4) Menyusun alat evaluasi pembelajaran berdasarkan perkembangan untuk dilaksanakan pada siklus II serta menyiapkan instrumen pendukung pembelajaran lainnya.

Selama pembelajaran langsung dilakukan observsi untuk mengetahui prosedur pelaksanaan pemebelajaran Make a Match dalam meningkatkan hasil belajar pada proses pembelajaran produk kreatif dan kewirausahaan . Langkah selanjutnya bagi peneliti adalah pelaksanaan. Pada tahap ini perencanaan yang sudah dibuat peneliti akan dilaksanakan dalam kegiatan pembelajaran. Tahap pengamatan atau observasi dilakukan bersamaan dengan pelaksanaan tindakan. Pada tahap ini peneliti di bantu oleh guru atau teman sejawat untuk mencatat semua hal yang diperlukan dalam penelitian berupa pengumpulan data.

Ketika dilaksanakan kegiatan pembelajarankebanyakan siswa yang tidak tahu dan tidak paham, sehingga tidak bisa menjawab pertanyaan yang berkenaan dengan soal-soal yang berhubungan dengan "organ peredaran darah dan fungsinya". Karena ketidakpahaman dan ketidakmapuan dalam menjawab soal-soal yang berhubungan dengan "organ darah dan fungsinya" suasana kelas tampak gaduh dan sulit dikendalikan.

Tahap yang terahir merupakann kegiatan untuk mengemukakan kembali apa yang sudah dilakukan. Istilah refleksi berasal dari kata bahasa Inggris reflection yang diterjemahkan dalam bahasa Indonesia. Pada tahap ini peneliti menyimpulkan data atau hasil yang diperoleh selama proses penelitian itu berlangsung. Selain itu juga dimaksudkan sebagai upaya untuk memahami proses, masalah, persoalan, dan kendala nyata dalam proses tindakan. Dalam hal ini peneliti melakukan penilaian sebagai tugas akhir dari siklus.

\section{Hasil dan Pembahasan}

Data hasil pretes kelompok siswa sebelum mendapat Pembelajaran dengan menggunakan media pembelajaran Make a Match, dianalisis untuk mengetahui tingkat pengetahuan dan pemahaman tentang materi belajar yang berhubungan dengan materi "Organ peredaran darah dan fungsinya". Hasil belajar siswa terlihat bahwa nilai pretes kelompok siswa sebelum mendapat perlakuan pembelajaran dengan model pembelajaran Make a Match adalah 68,65.

Perencanaan di mulai dengan membentuk kelompok diskusi. Siswa yang berjumlah 23 siswa dibagi menjadi 4 kelompok sehingga masing-masing kelompok berjumlah 6 siswa. Materi pelajaran yang diajarkan pada siklus I ini adalah pokok bahasan organ peredaran darah dan fungsinya. Proses pembelajaran ini menggunakan model pembelajaran Make a Match yang diterapkan oleh guru secara langsung dalam pembelajaran di kelas.

\section{Siklus I}

Kegiatan yang dilakukan oleh peneliti pada tahap perencanaan adalah: 1) Peneliti melakukan analisis kurikulum untuk menentukan standar kompetensi dan kompetensi dasar yang disampaikan 
kepada siswa dengan menggunakan pembelajaran Make a Match Membuat RPP siklus I dengan model pembelajaran dengan media pembelajaran Make a MatchMembuat lembar observasi siklus I untuk melihat bagaimana kondisi belajar mengajar dikelas ketika latihan dan kerja kelompok dilaksanakan. 2)Membuat Lembar Kerja Siswa siklus I. 3) Membentuk kelompok (terdiri dari 6 siswa) yang bersifat heterogen baik dari segi kemampuan akademis, jenis pembelajaran dengan model pembelajaran Make a Match pada siklus I. dan 4) Menyusun alat evaluasi pembelajaran berdasarkan perkembangan pada siklus II serta menyiapkan instrumen pendukung pembelajaran lainnya.

Pelaksanaan kegiatan belajar mengajar pembelajaran dengan media pembelajaran Make a Match untuk siklus I dengan jumlah siswa 23 siswa. Dalam hal ini Peneliti bertindak sebagai guru. Pengamatan (observasi) dilaksanakan bersamaan dengan pelaksanaan pembelajaran. Pelaksanaan tindakan siklus I dapat diuraikan sebagai berikut: 1) Guru mengawali pembelajaran dengan mengucapkan salam dan menanyakan jumlah siswa yang hadir. 2) Guru melaksanakan apersepsi. 3) Guru membagi siswa dalam kelompok diskusi, kemudian memberi tugas yang berkaitan dengan penggunaan model pembelajaran Make a Match. 4) Guru memberi tugas kepada siswa untuk mempresentasikan di depan kelas hal-hal yang berkaitan dengan "organ peredaran darah dan fungsiny" dengan menggunakan model pembelajaran Make a Match, waktu untuk presentasi adalah 5 menit untuk masing-masing individu. 5) Guru menindaklanjuti pembelajaran itu dengan menerangkan materi pelajaran tentang hal-hal yang berkaitan dengan "organ peredaran darah dan fungsinya" menggunakan model pembelajaran Make a Match, waktu yang digunakan selama 10 menit. 6) Guru bersama-sama siswa mendemonstrasikan penggunaan pembelajaran Make a Match materi "organ peredaran darah dan fungsinya" selama 10 menit. 7) Guru bersama-sama siswa melakukan kegiatan pembelajaran dengan tema "organ peredaran darah dan fungsinya 8) Guru memberikan tugas secara individu selama 15 menit 9) Guru menutup pelajaran dengan mengucapkan salam.

Dalam siklus pertama ini, berdasarkan catatan peneliti, siswa masih kurang dapat bekerja sama, kerja kelompok masih kurang dapat berjalan sebagaimana yang diharapkan, presentasi belum banyak mendapat perhatian/tanggapan dari pendengar (siswa dari kelompok lain).

Selama pembelajaran berlangsung dilakukan observasi untuk mengetahui pengaruh kegiatan pembelajaran dalam meningkatkan hasil belajar siswa tema "organ peredaran darah dan fungsinya". Pada pembelajaran ini siswa yang masuk sebanyak 23 siswa.

Guru mengamati, ternyata pada setiap kelompok masih didapati siswa yang kurang memperhatikan pelajaran yang berkaitan dengan materi "organ peredaran darah dan fungsinya" dan masih berbicara dengan teman didekatnya tentang hal-hal yang tidak berkaitan dengan materi pembelajaran. Melalui serangkaian pertanyaan yang disampaikan kepada siswa, sebagian diantaranya belum memahami dan bahkan tidak tau apa yang di diskusikan dalam kelompoknya. Adapun hasil belajar siswa setelah kegiatan yang diberikan dalam Siklus I, dapat dilihat di tabel 01 berikut.

Tabel 01. Tabel Siklus 1 Hasil Belajar Siswa dalam Siklus 1

\begin{tabular}{clcc}
\hline No & \multicolumn{1}{c}{ Nama Siswa } & Nilai & Predikat \\
\hline 1 & Ahmad Rouf Firmansyah & 80 & Tuntas \\
2 & Ainul Ma'ruf & 70 & Tuntas \\
3 & Alif Firdaus Aisyabi & 70 & Tuntas \\
4 & Aura Sakinah Putri & 80 & Tunas \\
5 & Azahwa Putri Wahyuni & 60 & Belum Tuntas \\
6 & Emiliya Fanda Lestari & 60 & Belum Tuntas \\
7 & Eriska Putri Gunawan & 70 & Tuntas \\
8 & Firdatul Jannah & 80 & Tuntas \\
9 & Habibi Nur Rohmatulloh & 50 & Belum Tuntas \\
10 & Intan Nur Lestari & 60 & Belum Tuntas \\
11 & Maulana Ixbal & 70 & Tuntas \\
12 & Khalwa Maharani & 70 & Tuntas \\
13 & Laily Sofia & 90 & Tuntas \\
14 & Mario Eko Prasetyo & 60 & Belum Tuntas \\
15 & Meisya Aura Nafisa & 75 & Tuntas \\
16 & M. Rafi Amrulloh & 70 & Tuntas \\
17 & Mustika Anggraeni & 60 & Belum Tuntas \\
\hline
\end{tabular}




\begin{tabular}{clcc}
\hline 18 & Nikita Winne Audrea & 80 & Tuntas \\
19 & Nur Lailah & 60 & Belum Tuntas \\
20 & Rahlil Ahmad Billal R & 90 & Tuntas \\
21 & Tri Prisma Wulandari & 80 & Tuntas \\
22 & Vidia Arga Sampurna & 60 & Belum Tuntas \\
23 & Wisnu Ahmad Dwi S & 60 & Belum Tuntas \\
& Jumlah & 2460 & \\
& Rata-Rata & 70.28 & \\
\hline
\end{tabular}

Berdasarkan Tabel 01 tersebut dapat dikatakan bahwa hasil belajar siswa mengalami peningkatan yang cukup signifikan. Pada Siklus I diperoleh rata-rata nilai 71,615 $(<70,00)$. Hasil tersebut menunjukkan bahwa secara umum, siswa belum tuntas secara keseluruhan.

Berdasarkan Tabel di atas jumlah nilai observasi kegiatan siswa belum memuaskan menurut kategori tingkat keaktifan siswa, berarti dalam mengikuti pelajaran siswa masih kurang aktif, karena anggota kelompok masih terlalu banyak dan siswa belum terbiasa diskusi. Maka pada pertemuan selanjutnya peneliti yang sekaligus sebagai guru menyimpulkan bahwa perlu diadakan siklus selanjutnya. Pada siklus I peneliti akan melanjutkan penerapan model pembelajaran Make a Macth pada proses pembelajaran IPA

Dalam pelaksanaan kegiatan belajar mengajar pada siklus I yang masih terdapat kekurangankekurangan, Maka perlu adanya revisi untuk dilakukan pada siklus II antara lain : 1) Guru dalam memotifasi siswa hendaknya dapat membuat siswa lebih termotivasi selama proses belajar mengajar berlangsung. 2) Guru harus lebih dekat dengan siswa sehingga tidak ada perasaan takut dalam diri siswa, sehingga siswa lebih berkosentrasi dalam pembelajaran yang berkenaan dengan "organ peredaran darah dan fungsinya". 3) Guru harus lebih bersabar dalam membimbing siswa berdiskusi untuk menemukan hal-hal baru yang berkaitan dengan. 4) Guru harus mendistribusikan waktu secara baik sehingga kegiatan pembelajaran sesuai dengan yang diharapkan. Dan 5) Guru sebaiknya menambah lebih banyak contoh soal dan memberi soal-soal latihan pada siswa untuk dikerjakan pada setiap kegiatan pembelajaran.

\section{Siklus II}

Perencanaan di mulai dengan membentuk kelompok diskusi. Siswa yang berjumlah 23 siswa dibagi menjadi 6 kelompok sehingga masing-masing kelompok berjumlah 4 siswa. Materi pelajaran yang diajarkan pada siklus 2 ini tetap pada "organ peredaran darah dan fungsinya". Proses pembelajaran pokok bahasan "organ peredaran darah dan fungsinya" ini menggunakan model pembelajaran Make a Macth yang diterapkan oleh guru dalam pembelajaran di kelas.

Pelaksanaan tindakan siklus II dapat diuraikan sebagai berikut: 1) Guru mengawali pembelajaran dengan mengucapkan salam dan menanyakan jumlah siswa yang hadir. 2) Guru melaksanakan apersepsi. 3) Guru membagi siswa dalam kelompok diskusi, kemudian memberi tugas yang berkaitan dengan penggunaan model pembelajaran Make a Match. Guru memberi tugas kepada siswa untuk mempresentasikan di depan kelas hal-hal yang berkaitan "organ peredaran darah dan fungsinya" penggunaan model pembelajaran Make a Macth, waktu untuk presentasi adalah 3 menit untuk masingmasing kelompok. 4) Guru menindaklanjuti pembelajaran itu dengan menerangkan materi pelajaran tentang hal-hal yang berkaitan dengan "organ peredaran darah dan fungsinya" menggunakan media interaktif, waktu yang digunakan selama 10 menit. 5) Guru bersama-sama siswa mendemonstrasikan penggunaan model pembelajaran materi "organ peredaran darah dan fungsinya" selama 10 menit. 6) Guru bersama-sama siswa melukukan kegiatan pembelajaran materi "organ peredaran darah dan fungsinya" 7) Guru memberikan tugas secara individu selama 15 menit. Dan 8) Guru menutup pelajaran dengan mengucapkan salam.

Selama pembelajaran berlangsung dilakukan observasi untuk mengetahui pengaruh kegiatan pembelajaran dalam meningkatkan hasil belajar siswa dalam proses pembelajaran materi "organ peredaran darah dan fungsinya". Pada pembelajaran ini siswa yang masuk sebanyak 23 siswa. Guru mengamati, ternyata setiap kelompok siswa memperhatikan pelajaran yang berkaitan dengan "organ peredaran darah dan fungsinya" dengan baik, dan tidak lagi berbicara dengan teman didekatnya tentang hal-hal yang tidak berkaitan dengan materi pembelajaran.

Tabel 02. Hasil Siklus II Nilai Tes Formatif Siswa dalam Siklus 2

\begin{tabular}{|c|c|c|c|}
\hline No & Nama Siswa & Nilai & Predikat \\
\hline 1 & Ahmad Rouf Firmansyah & 80 & Tuntas \\
\hline
\end{tabular}




\begin{tabular}{clcc}
\hline 2 & Ainul Ma'ruf & 70 & Tuntas \\
3 & Alif Firdaus Aisyabi & 80 & Tuntas \\
4 & Aura Sakinah Putri & 90 & Tunas \\
5 & Azahwa Putri Wahyuni & 80 & Tuntas \\
6 & Emiliya Fanda Lestari & 80 & Tuntas \\
7 & Eriska Putri Gunawan & 80 & Tuntas \\
8 & Firdatul Jannah & 90 & Tuntas \\
9 & Habibi Nur Rohmatulloh & 60 & Belum Tuntas \\
10 & Intan Nur Lestari & 90 & Tuntas \\
11 & Maulana Ixbal & 80 & Tuntas \\
12 & Khalwa Maharani & 75 & Tuntas \\
13 & Laily Sofia & 70 & Tuntas \\
14 & Mario Eko Prasetyo & 90 & Tuntas \\
15 & Meisya Aura Nafisa & 80 & Tuntas \\
16 & M. Rafi Amrulloh & 80 & Tuntas \\
17 & Mustika Anggraeni & 70 & Tuntas \\
18 & Nikita Winne Audrea & 80 & Tuntas \\
19 & Nur Lailah & 90 & Tuntas \\
20 & Rahlil Ahmad Billal R & 80 & Tuntas \\
21 & Tri Prisma Wulandari & 80 & Tuntas \\
22 & Vidia Arga Sampurna & 90 & Tuntas \\
23 & Wisnu Ahmad Dwi Suherman & 60 & Belum Tuntas \\
& Jumlah & 2814 & \\
& Rata-Rata & 80.4 & \\
& & & \\
\hline
\end{tabular}

Sumber Data : Hasil Ulangan Harian Siswa

Dari tabel 02 di atas dapat diketahui bahwa dengan menerapkan pembelajaran dengan model pembelajaran Make a Match tampak bahwa nilai rata-rata siswa adalah 70,28 dengan nilai terendah 60 dan nilai tertinggi 79. Nilai ketuntasan belajar adalah 70,00 jumlah siswa yang mendapat nilai $\geq 70,00$ sebanyak 23 siswa, yang berarti $75 \%$ dari sejumlah 23 siswa memiliki nilai di atas taraf penguasaan konsep yang diberikan, lebih kecil dari persentase ketuntasan yang dikehendaki yaitu sebesar $95 \%$. Hal ini disebabkan karena siswa masih baru dan asing terhadap metode baru yang diterapkan dalam proses belajar mengajar. Sehingga dapat dikatakan siswa belum banyak memahami tentang konsep pokok bahasan yang dibahas.

Dalam pelaksanaan kegiatan belajar mengajar pada siklus I yang masih terdapat kekurangankekurangan, Maka perlu adanya revisi untuk dilakukan pada siklus II antara lain : 1) Guru dalam memotifasi siswa hendaknya dapat membuat siswa lebih termotivasi selama proses belajar mengajar berlangsung. 2) Guru lebih dekat dengan siswa sehingga tidak ada perasaan takut dalam diri siswa, sehingga siswa lebih berkosentrasi dalam pembelajaran. 3) Guru lebih bersabar dalam membimbing siswa berdiskusi untuk menemukan hal-hal baru yang berkaitan dengan materi pembelajaran. 4) Guru secara intensif memberikan pengertian kepada siswa kondisi dalam berkelompok, kerjasama kelompok, dan keikutsertaan siswa dalam kelompok. 5) Guru mengubah jumlah siswa (dari 4 siswa menjadi 3 siswa) dalam satu kelompok. 6) Guru membantu kelompok yang belum memahami langkah-langkah pembelajaran dengan model Make a Match. 7) Guru memberikan dorongan dan motivasi kepada siswa untuk lebih aktif mencari sumber belajar, diharapkan agar siswa memperoleh hasil yang diharapkan.

Sebelum perlakuan diberikan pada masing-masing kelompok, nilai rerata pretes siswa sebelum diberi perlakuan pembelajaran dengan modelMake a Matchadalah 68,65. Setelah siswa diberi perlakuan pembelajaran dengan media pembelajaran Make a Match pada siklus I mengalami peningkatan menjadi 70.28, namun hasil ini belum memenuhi target hasil belajar siswa mata pelajaran tematik yaitu $95 \%$. Bila dihitung berdasarkan nilai rerata pretes, kelompok siswa yang diberi perlakuan pembelajaran dengan Make a Match setelah dilaksanaknnya siklus ke II mengalami peningkatan rerata hasil belajar sebesar $80,400-68,65=11,75$.

Berdasarkan hasil pada sisklus penelitian tersebut di atas, dapat ditunjukkan bahwa ada perbedaan hasil belajar materi "organ peredaran darah dan fungsinya" antara siswa yang diajar menggunakan metode pembelajaran Make a Match. Hasil penelitian ini juga didukung oleh hasil penelitian (Nugraheni, 2016) yang menyatakan bahwa ada perbedaan hasil belajar siswa yang yang mendapat perlakuan pembelajaran dengan model pembelajaran Make a Match memperoleh rata-rata nilai sebesar 80,400, lebih tinggi daripada sebelum siswa diajar dengan model pembelajaran lainnya, yaitu 68,65 
Penerapan media Make a Match memberikan peningkatatan yang lebih baik pada perolehan hasil belajar siswa daripada penerapan pembelajaran dengan metode lainya. Dengan kata lain dapat di interpretasikan bahwa penerapan pembelajaran dengan Make a Match dapat meningkatkan perolehan hasil belajar siswa pada materi "organ peredaran darah dan fungsinya".

\section{Simpulan dan Saran}

Berdasarkan Penerapan pembelajaran dengan metode Make a Match, terjadi peningkatan yang lebih baik pada perolehan hasil belajar siswa jika dibandingkan dari penerapan pembelajaran dengan metodel sebelumnya. Dengan kata lain dapat diinterpretasikan bahwa penerapan pembelajaran dengan metode Make a Match dapat meningkatkan perolehan hasil belajar siswa daripada dengan model pembelajaran konvensinal. Hal ini berdasarkan nilai rerata pretes dimana rata-rata hasil belajar siswa sebesar 68,65, sedangkan setelah siswa diberi perlakuan pembelajaran dengan media Make a Match setelah dilaksanakannya siklus ke II mengalami peningkatan rerata hasil belajar sebesar 80,400 artinya terjadi peningkatan rerata hasil belajar siswa sebesar 11,65.

\section{Daftar Rujukan}

Daliyawati. (2016). Upaya Meningkatkan Prestasi Belajar Mata Pelajaran Ipa Rangkaian Seri Dan Rangkaian Paralel Melalui Metode Eksperimen Siswa Kelas VI SD N 10 Ujan Mas. Jurnal Ilmiah Pendidikan Guru Sekolah Dasar, 9(3), 313-320.

Dimyati \& Mudjiono. (2016). Belajar dan Pembelajaran. Rineka Cipta.

Hamalik, O. (2004). Proses Belajar Mengajar. Bumi Aksara.

Jihad Asep, A. H. (2012). Evaluasi Pembelajaran. Multi Presindo.

Kurnia, R. (2014). Keefektifan Model Pembelajarankooperatif Tipe Make A Match di Kelas III Sekolah Dasar. Journal of Elementary Education, 3(1), 34-40.

Lestari, N, D. (2017). Memajukan Kewirausahaan dalam Upaya Membangun Indonesia.

Nugraheni, S. A. (2016). Menguak Belantara Autisme. Buletin Psikologi, 20(1-2), 9-17. https://doi.org/10.22146/bpsi.11944

Sudjana, N. (2010). Proses dan Hasil Belajar. Bumi Aksara.

Suprijono, A. (2013). Cooperative Learning Teori dan Aplikasi PAIKEM. Pusaka Belajar.

Suryosubroto, B. (1997). Proses Belajar Mengajar Di Sekolah. PT. Rineksa Cipta.

Susanto, A. (2013). Teori Belajardan Pembelajaran di Sekolah Dasar. Kencanaprenada media group.

Tilaar, H. (1999). Beberapa Agenda Reformasi Pendidikan Nasional : Dalam Perspektif Abad 21. Indonesia Tera. 